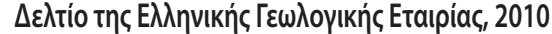

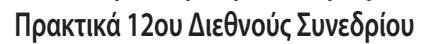

Пátpa, Máıoc 2010
Bulletin of the Geological Society of Greece, 2010

Proceedings of the 12th International Congress

Patras, May, 2010

\title{
TECTONIC SETTING AND DEFORMATION OF THE KALLIDROMO MT, CENTRAL GREECE
}

\author{
Migiros G. ${ }^{1}$, Antoniou Vas. ${ }^{1}$, Papanikolaou $\mathbf{I}^{1}{ }^{\text {and Antoniou Var. }}{ }^{2}$ \\ ${ }^{1}$ Laboratory of Mineralogy \& Geology, Department of Geological Sciences and Atmospheric \\ Environment, Agricultural University of Athens, 75 Iera Odos Str., 11855 Athens - GR \\ bagm@aua.gr,vantoniou@aua.gr,i.papanikolaou@ucl.ac.uk \\ ${ }^{2}$ Department of Dynamic, Tectonic and Applied Geology, National and Kapodistrian University of Athens, \\ Faculty of Geology and Geoenvironment, Panepistimioupolis Zografou, 157-84 Athens, \\ Greece,vantoniou@geol.uoa.gr.
}

\begin{abstract}
Kallidromo Mt. consists of alpine formations which in places are unconformably covered by Neogene and Quaternary sediments. The ophiolites are overthrusted on the massive Mesozoic platform carbonate sequence, which forms the basement unit. The base of the tectonic nappe is characterized by a tectonic melange that consists of sandstones, clay stones, limestones, cherts and basaltic rocks that are mainly observed in pillow forms. Two distinct compressional deformation phases $(D 1, D 2)$ are traced. Deformation D1 whereas the fold axes, the predominant schistocity planes and shear zones clearly follow a $295^{\circ}\left( \pm 10^{\circ}\right)-115^{\circ}\left( \pm 10^{\circ}\right)$ trend that relates to the Upper Jurrasic-Lower Cretaceous ophiolitic emplacement of the Eo-alpine orogeny and is the predominant feature over the entire study area. Deformation D2 relates to the Cretaceous-Eocene alpine orogeny, follows a $N 020^{\circ}\left( \pm 15^{\circ}\right)-N 200^{\circ}\left( \pm 15^{\circ}\right)$ trend and has a much weaker and secondary imprint in the study area. The tectonic study of the alpine and post-alpine formations shows a complex deformation pattern with a variety of quantitative and qualitative characteristics. These variations can be correlated with different phases and stages of deformation (compressional to extensional) from the timing of the tectonic emplacement of the ophiolites inUpperJurrasic-Lower Cretaceous up to the present-day field.
\end{abstract}

Key words: Kallidromo, ophiolites, structural analysis, fault.

\section{Introduction}

Mt Kallidromo is an elongated WNW-ESE trending mountain in central Greece and represents a tectonic horst (e.g. Phillip 1974, Goldsworthy and Jackson 2001) between the Sperchios basin northwards and the Beotikos Kifissos basin southwards (Fig.1). The major watershed follows the WNWESE elongation of the Kallidromo Mt at 900m elevation. The river network within the alpine rocks is of dendritic type involving mostly small catchments of lower stream order $\left(1-4^{\text {th }}\right.$ based on Strahler classification), whereas within the post-alpine rocks the network is represented by single nodes, involving a more mature network that includes large catchments or small rivers (of $4^{\text {th }}$ and higher stream order), exhibiting a higher hierarchical structure. The Sperchios is a narrow basin trending WNW-ESE, forming the inland prolongation of the Maliakos and Northern Evoikos Gulfs. It is characterized by smoothed landscape with a $50 \mathrm{~m}$ mean elevation and dips gently towards the south, due to the higher fault slip-rate activity of the faults bordering its southern boundary. The Beotikos Ki- 


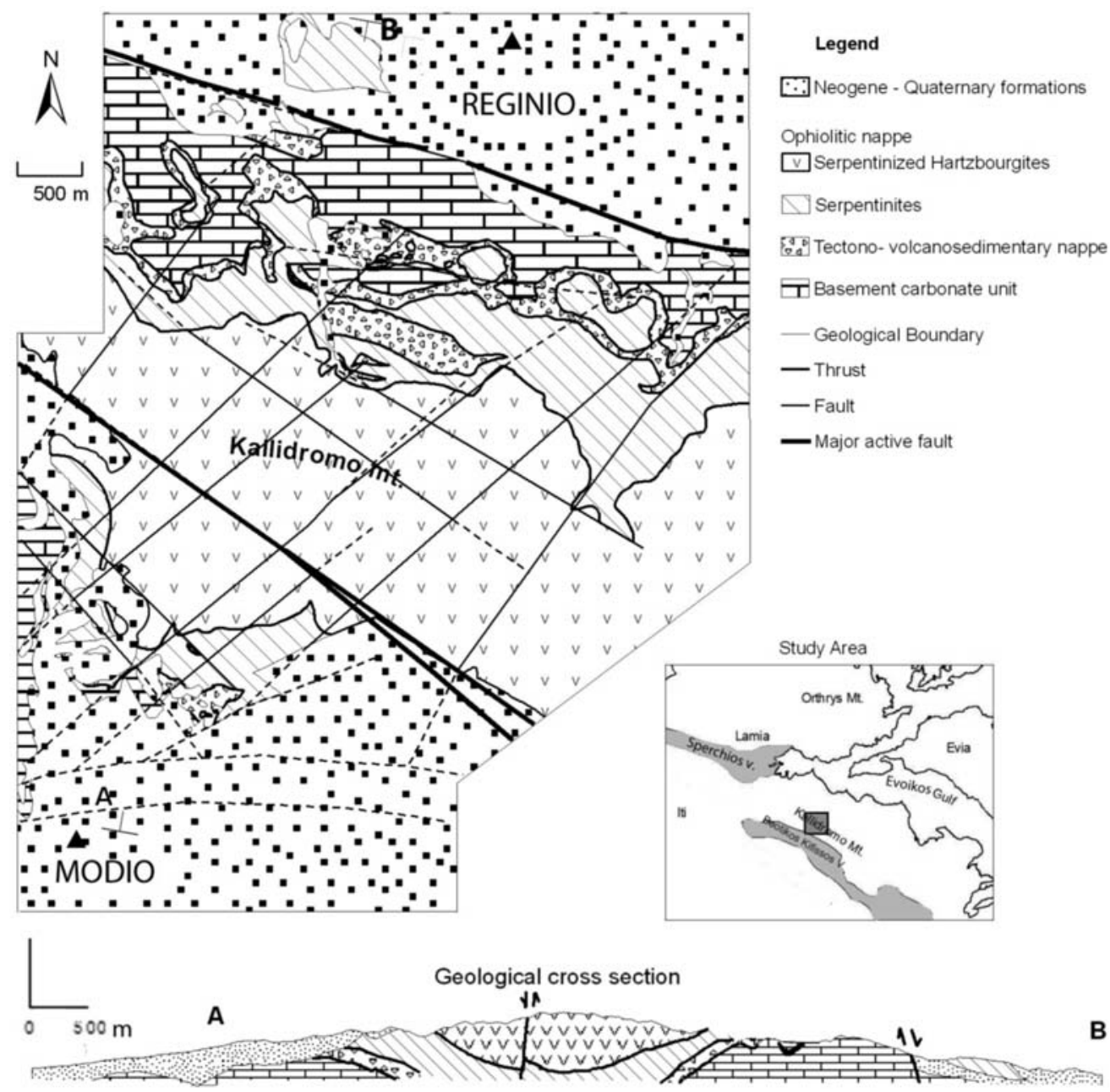

Fig 1: Geological map of the study area.

fissos is a rather shallow basin where the postalpine sedimentary cover is thin, so that the Mesozoic rocks crop at several localities within the basin. It also trends WNW-ESE and has a mean elevation at $150 \mathrm{~m}$. This paper examines and presents the lithostratigraphic and tectonic structure of the Kallidromo Mt and analyzes their interrelation.

\section{Geological structure}

Kallidromo Mt comprises Mesozoic limestones, schist-cherts with basalts, ultramafic rocks and flysch of the Pelagonian zone (Papastamatiou et al., 1962, Celet 1962, Clement 1977, Fleury, 1980, Ferriere 1982, Karipi et al. 2007). It is part of the Internal Hellenides (Brunn, 1956), that has been subdivided by Aubouin (1959) into a non-metamorphic western (Subpelagonian zone e.g. Mountrakis et al. 1983, Papanikolaou 1989) and a metamorphic eastern part (Pelagonian zone s.s.; for an 

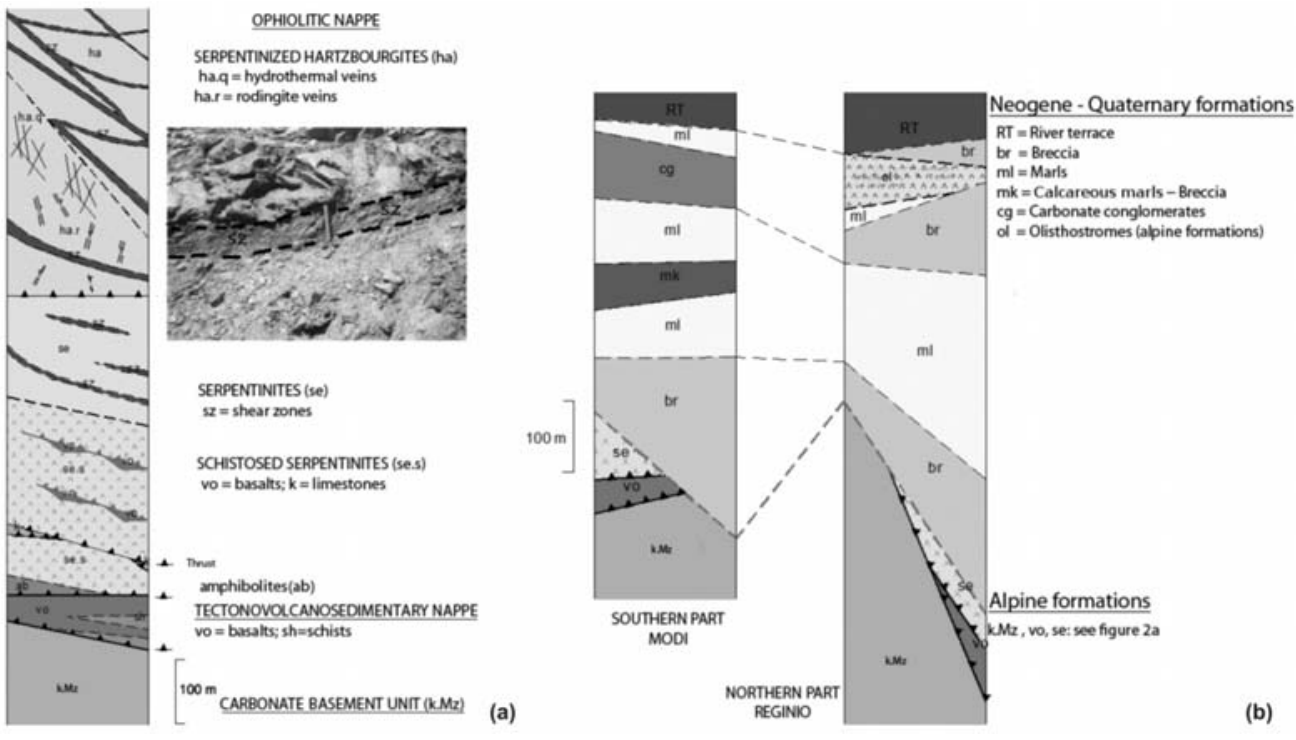

Fig 2: a) Lithostratigraphic column of the Alpine formations of the Kallidromo Mt. b) The post-alpine formations and the alpine basement for the northern (Reginio) and the southern part (Modi) of the study area.

overview see Jacobshagen 1986). Palaeo-geographically, the Pelagonian zone s.l. is considered to be a continental fragment, which was bordered at its internal and external margins by oceanic domains that have been traditionally called the Vardar and Pindos Oceans respectively (Bernoulli and Laubscher, 1972; Jones and Robertson, 1991). The Pelagonian exhibits a complex nappe structure due to repeated thrusting and ophiolite obduction processes from the oceanic realms during the Alpine orogeny. The subduction of the oceanic domains initiated in the Mid-Jurassic and lasted until early Tertiary times and was accompanied by the formation of ophiolite complexes, blueschist belts and ended up by the flysch sedimentation (Smith and Woodstock 1976; Katsikatsos et al. 1986; Jones and Robertson 1991; Faupl et al. 1996). Neogene and Quaternary deposits and sediments rest uncomformably on the alpine rocks both northwards (Reginio into the Sperchios basin) and southwards (Modi into the Beotian basin) and are bounded by active normal faults (Celet 1962, Phillip 1974, Ganas 1997, Kranis 1999, Goldsworthy and Jackson 2001). In the following section a detailed description of the local geological structure is presented regarding the wider Kallidromo Mt.

\subsection{Alpine Formations}

The Alpine formations are divided into three major units that from lower to upper members consist of: a) the carbonate basement unit, b) the tectonovolcanosedimentary nappe and c) the ophiolitic nappe. Both the ophiolitic and the tectonovolcanosedimentary nappes are thrusted on top of the carbonate basement unit, which represents the Mesozoic neritic platform (Fig.2a).

a) Carbonate basement unit. It comprises fossiliferous Mesozoic carbonate sequence of limestones and dolomites. In a few localities within the limestones, several beds of clay schists intercalations also appear, indicating a temporally deeper sedimentation environment. Towards the northern part of the study area, the limestones appear more crystalline, dolomitised and fragmented. During the prolonged thrusting emplacement several fault planes were developed as documented by the extensive fault zones of various thicknesses (from 5 up to $20 \mathrm{~m}$ thick) that involve mostly breccia and to 
a lesser extend cataclasites.

b) Tectonovolcanosedimentary nappe. This nappe appears always thrusted on top of the carbonate basement unit and below the ophiolitic nappe. It consists of clay-chert and marly limestones formations with basalts of various thicknesses. Basalts are represented by pillow lavas, whose thickness varies from 40 to $100 \mathrm{~m}$. The entire formation is highly deformed, folded and fragmented as evidenced by the extensive appearance of thick breccia and other cataclasites.

c) Ophiolitic nappe. The ophiolitic nappe covers the entire central part of the Kallidromo Mountain and has a maximum structural thickness of $900 \mathrm{~m}$. Three subunits are defined, that from lower to upper members involve: (a) schistosed serpentinites, (b) serpentinites and (c) serpentinized hartzbourgites. Subunits (a) and (b) form a common mass whose deformation is gradually reduced, up to subunit (c) that is thrusted on top of the others. Towards the base of the ophilitic nappe several amphibolite bodies of various thickness are evident, comprising the so-called "amphibolitic sole". The amphibolites (ab) form discontinuous bodies whose thickness varies from 1 up to $20 \mathrm{~m}$. They are often folded and in several cases a cataclastic fabric/texture has been traced (Fig.2a).

Schistosed serpentinites (se.s). Schistosed serpentinites form an heterogenous mass that maintain a highly foliated structure. This foliation was developed due to the intense deformation processes that occurred both during the initial stages of their emplacement as well as during their overthrust on the carbonate basement unit. Such intense deformation processes resulted in internal repetition of the serpentinites. These repetitions that are tectonically controlled can increase locally their thickness up to a significant amount (180m towards the northern part and up to $320 \mathrm{~m}$ towards the southern part where deformation is more intense). In particular, towards the southern part of the study area, several lenticular bodies of variable sizes of limestones and volcanosedimentary formations are traced along strike these thrusts. Several shear zones of brittle type, whose thickness range from a few $\mathrm{cm}$ up to $5 \mathrm{~m}$. Finally, in several localities, they appear as a mixture of rocks involving different lithological compounds and forming a mosaic. Such mixtures can locally be characterized as "ophiolitic mélanges". Beyond the serpentinites that dominate mélange, several other rocks such as amphibolites, dolerites, basalts, sandstones, limestones and cherts, do also exist.

Serpentinites (se). The schistosed serpentinites evolve upwards into the serpentinites, which are intensely deformed in a boudinage style. Their boundary with the schistosed serpentinites is often unclear, whereas the intensity of the deformation that have experienced, diminishes towards their upper members. Their thickness is up to $200 \mathrm{~m}$, but in a few localities they are absent due to the tectonic wedges between the schistosed serpentinites and the thrusted serpentinized hartzbourgites. Their structure is trending parallel to the approximately E-W trending ophilitic elongated nappe. Shear zones are observed within the serpentinites and particularly as approaching the thrust with the overlying serpentinized hartzbourgites. These shear zones are of brittle type and their thickness varies from a few cm up to $20 \mathrm{~m}$.

Serpentinized Hartzbourgites (ha). The serpentinized harzburgites have a thickness up to 500m and are interrupted by various shear zones. These shear zones are either of pure brittle nature or developed on the brittle-ductile boundary and their thickness varies from a few $\mathrm{cm}$ up to $50 \mathrm{~m}$. The major shear zones follow a mean WNW-ENE direction. Depending on the presence or not of veins they are divided into two main parts, whose boundary, however is in most cases unclear. The body of the serpentinized hartzbourgites that is crosscuted by veins and vents, does not exhibit any petrological differentiation from the body of the serpentinised harzburgite, except from a slightly higher degree of serpentinisation and in places hydrothermal alterations. The circulation of hydrothermal fluids after the rock formation causes serpentinization and alteration of the peridotites, which are converted 
to serpentines. During serpentinization ultramafic rocks are oxidized with water into serpentinite. Since during the serpentinization process, rock temperatures can be raised as high as $250^{\circ} \mathrm{C}$, formation of non-volcanic hydrothermal vents may take place. The veins are divided into two systems: a) The first system of veins comprise from rodingites and rodingite gabbros (ha.r) (Coleman, 1977) that are intensely deformed and vary in thickness from a few $\mathrm{cm}$ up to $4 \mathrm{~m}$. b) The second system of veins and vents concerns the hydrothermal processes that occurred following the postgabbro intrusion stage.

\subsection{Postalpine formations}

The postalpine formations outcrop predominantly towards the northern and southern part of the study area, and cover unconformably the alpine formations. Figure $2 \mathrm{~b}$ displays the columns including also the basement alpine rocks. Since their features, facies and thicknesses differ significantly between the northern (Reginio) and the southern part (Modi), two separate columns are displayed. They are divided into:

a) Upper Pliocene - Lower Pleistocene Formations

Breccia $(b r)$. It is a cohesive formation that consists of various sizes of mostly angular and subangular fragments of rocks and pebbles. They are cemented with finer clastic material mostly sands and clay. They are poorly sorted; however they are rather well stratified. In several localities, several horizons and lenses of redsoil are interfingered as with other sediments as well. They have formed in a continental sedimentary basin that was tectonically controlled, so that in most cases they overlay a thin paleosoil, where a calcite horizon is nicely preserved. Their thickness is up to $250 \mathrm{~m}$.

Marls $(\mathrm{ml})$. An unconformity and in places a disconformity separates this formation from the older breccia formation. It is composed mostly of lagoonal type sediments such as clays and marls and locally some lenses and intercalations of gravels, sands and rarely conglomerates appear. Towards the northern part they are characterized by higher homogeneity, having a clear stratification, whereas in the southern part sedimentation processes were more complex and disturbed so that the material is more diverse and several intercalations occur both spatially and temporary. Its maximum thickness is estimated at $260 \mathrm{~m}$.

Calcareous marls $(\mathrm{mk})$. It represents a horizon within the marls formation, whose thickness ranges up to $60 \mathrm{~m}$. Towards the southern part of the study area, a well developed half a meter thick shear zone, is traced that was formed, due to its gradual sliding on top of the underlying marl formation.

Carbonate conglomerates - Breccia $(\mathrm{cg})$. It is a highly cohesive formation that overlays the marl formation. It outcrops only towards the southern part of the study area and on the upper part of the hilly landscape. It comprises monomict limestone breccia of various sizes with calcitic matrix. This formation has no stratification is poorly sorted and towards its base several coarse, angular fragments and limestone boulders are observed. Towards the northern part of the Kallidromo no similar formation exists. However, in a equivalent stratigraphic locality, several large scale slides of ophiolites are observed within the marl formation. Their presence within this formation north of the Kallidromo fault zone indicates that these sliding processes were related to tectonism that occurred during sedimentation.

b) Upper Pleistocene - Holocene deposits and sediments. They rest unconformably on the previous formations and are of continental origin. They involve, river terraces (RT), talus cones and triangular facets, scree, alluvial fans and deposits. The talus cones, breccia and scree extend along strike and delineate the Kallidromo fault zone. They consist mostly from limestone boulders and fragments and are strictly fault controlled. 

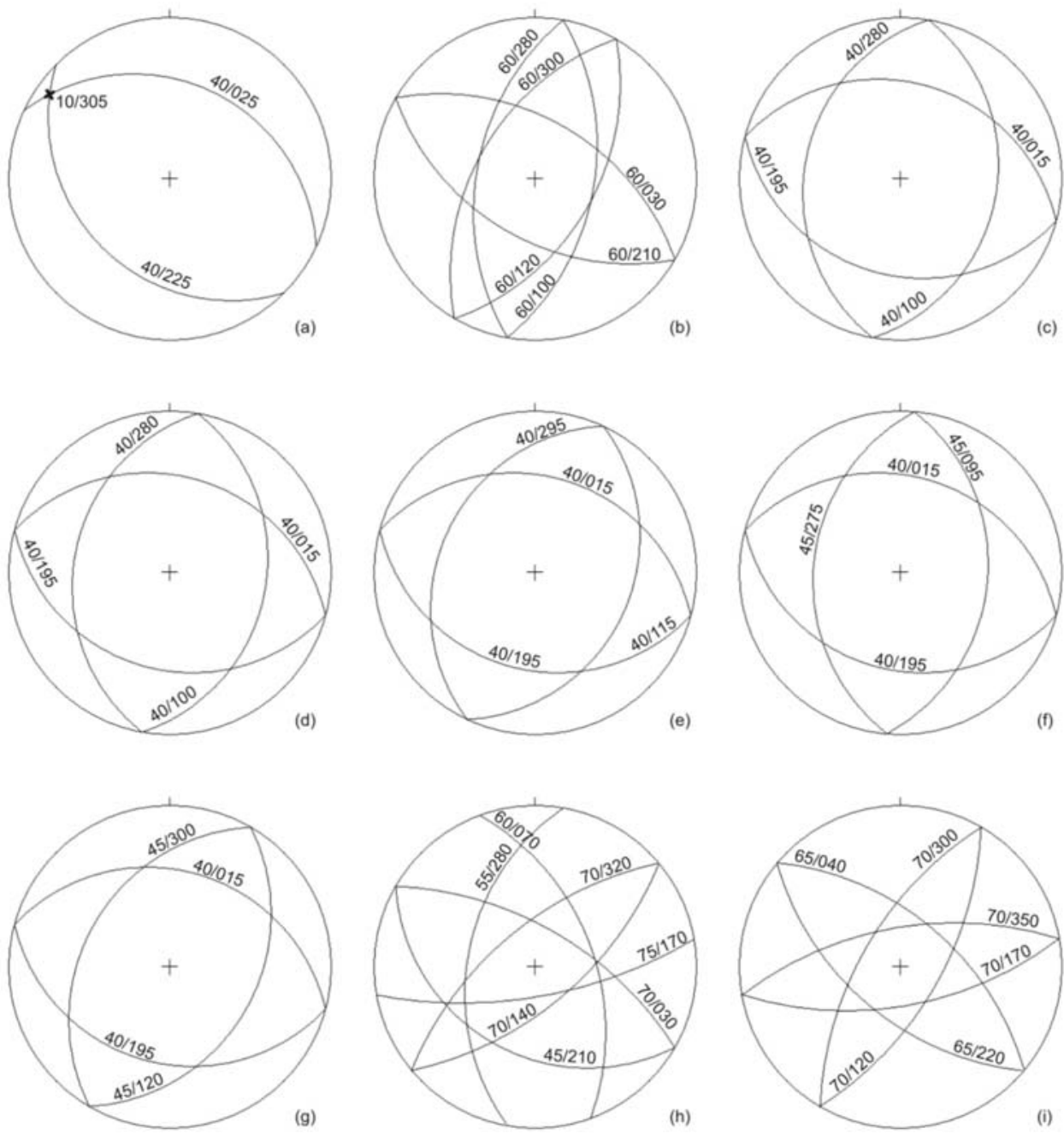

Fig 3: Schmidt stereograms and the mean values for Carbonates: a) The mean bedding planes and the fold axis, b) The three major joint systems. Volcanosendimentary formation: c) Schistocity planes, d) thrusts. Schistosed serpentinites and serpentinites: e) Schistocity. Serpentinized hartzbourgites: f) Schistocity, g) Shear zones, h) joint systems. (i) Faults.

\section{Structural Analysis}

Detailed structural analysis showed that the study area is characterized by tectonic features that were developed both within a compressive and extensional tectonic environment, including various qualitative and quantitative characteristics that relate to the different deformation phases that these rocks experienced through time. Tectonic analysis defined the directions and dip of the strata or the schistosity, geometric features of folding (fold axis, strike, dip and plunge direction), strike and dip of thrusts and shear zones, joints and faults. Statistical elaboration of the data is presented in the following Schmidt stereograms and the mean values are displayed separately for each alpine formation (Fig. 3). 


\subsection{Alpine formations}

a) Carbonate basement unit. The carbonate basement unit comprises mostly of thick-bedded or non stratified limestones so that no strata are clearly visible at its higher extend. Only towards the northern part of the study area strata dip at approximately $40^{\circ}$ both towards $\mathrm{NE}\left(\mathrm{N} 025^{\circ}\right)$ and $\mathrm{SW}\left(\mathrm{N} 225^{\circ}\right)$, due to folding (Fig. 3a). At the same area, strata are intensely folded with inclined folds, whose fold axes plunge $10^{\circ}$ towards $\mathrm{N} 305^{\circ}$. Overall, these features imply that the carbonates were deformed during the Eo-alpine orogeny from a NNE up to NE directed compressional field. Three joints systems are recognized (Fig. 3 b): a) N030 $-\mathrm{N} 210^{\circ}$ that dips $55^{\circ}-65^{\circ}$ both towards NW and SE, b) N010 ${ }^{\circ}$ $\mathrm{N} 190^{\circ}$ that dips $55^{\circ}-65^{\circ}$ towards $\mathrm{E}$ and $\mathrm{W}$ and c) $\mathrm{N} 300^{\circ}-\mathrm{N} 120^{\circ}$ that dips $60^{\circ}$ towards $\mathrm{NE}$ and $\mathrm{SW}$. The joint system that trends at $\mathrm{N} 300^{\circ}-\mathrm{N} 120^{\circ}$ is developed along strike the major folding axes, whereas the E-W and $\mathrm{N} 030^{\circ}-\mathrm{N} 210^{\circ}$ striking joint systems are transverse to the axes.

b) Nappe of the tectonovolcanosedimentary formations. This formation and predominantly the cherts are highly folded and fragmented. Only the schistocity could be defined. Two schistocity planes have been extracted (Fig. 3c): a) the primary at $\mathrm{N} 285^{\circ}-\mathrm{N} 105^{\circ}$, dipping $40^{\circ}$ both towards $\mathrm{NNE}$ and $\mathrm{SSW}$, and b) the secondary at $\mathrm{N} 010^{\circ}-\mathrm{N} 190^{\circ}$ that dips towards $40^{\circ}-45^{\circ}$ both towards $\mathrm{NW}$ and SE. The $\mathrm{N} 285^{\circ}-\mathrm{N} 105^{\circ}$ trending schistocity system is the predominant one covering almost $80 \%$ of the measurements, whereas the secondary one left a much weaker imprint. The $\mathrm{N} 285^{\circ}-\mathrm{N} 105^{\circ}$ trending schistocity system is parallel and in agreement with the thrusts measured within the same formation (Fig. 3d). These imply that the volcanosedimentary formations experienced an intense compressional deformation at NNE direction that is almost parallel and in agreement to their thrusting direction on the underlying carbonate basement unit.

c) Schistosed serpentinites and serpentinites. Measurements delineate two schistocity planes (Fig. 3e): a) is trending $\mathrm{N} 285^{\circ}-\mathrm{N} 105^{\circ}$, dips $40^{\circ}$ towards NNE and SSW and b) is trending $\mathrm{N} 025^{\circ}-\mathrm{N} 205^{\circ}$, dips $40^{\circ}$ towards NW and SE. The main thrusts are aligned and parallel to the schistocity planes. Serpentinites are deformed in a boudinage style whose long axis is parallel to the schistocity plane.

d) Serpentinized hartzbourgites. Two main schistocity planes are trending at: a) $N 005^{\circ}-\mathrm{N} 185^{\circ}$ and dipping $45^{\circ}$ towards $\mathrm{W}$ and $\mathrm{E}$ and b) $\mathrm{N} 105^{\circ}-285^{\circ}$ dipping $40^{\circ}$ towards NNE and SSW (Fig. 3f). Two main directions of shear zones are distinguished (Fig. $3 \mathrm{~g}$ ): a) $\mathrm{N} 030^{\circ}-\mathrm{N} 210^{\circ}$ that dips $45^{\circ}$ towards NW and SE and b) $\mathrm{N} 105^{\circ}-\mathrm{N} 285^{\circ}$ that dips $40^{\circ}$ towards NNE and SSW. Five main joint systems are rec-

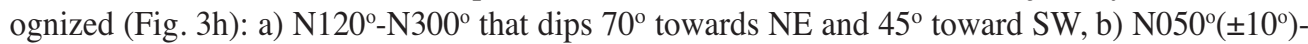
$\mathrm{N} 230^{\circ}\left( \pm 10^{\circ}\right)$ that dips $60^{\circ}-75^{\circ}$ towards NW and SE, c) N010 $-\mathrm{N} 190^{\circ}$ that dips $55^{\circ}$ towards WSW, d) $\mathrm{N} 340^{\circ}-\mathrm{N} 160^{\circ}$ that dips $60^{\circ}$ towards ENE, e) N080 $-\mathrm{N} 260^{\circ}$ that dips $75^{\circ}$ towards SSE.

\subsection{Faults and Neotectonics}

The study area is characterized by three major fault groups (Fig. 3i):

Group 1: It represents faults trending $\mathrm{N} 310^{\circ}-\mathrm{N} 130^{\circ}$ and dip at $60^{\circ}-70^{\circ}$ towards the NE and SW. They are normal and oblique normal both with sinistral or dextral slip. The rake is higher than $65^{\circ}$.

Group 2: It represents faults trending $\mathrm{N} 030^{\circ}-\mathrm{N} 210^{\circ}$ and dip at $60^{\circ}-80^{\circ}$ towards the NW and SE. They are normal and oblique normal both with sinistral or dextral slip. The rake ranges between $50^{\circ}-65^{\circ}$.

Group 3: It represents faults trending approximately E-W (N080 $\left.-\mathrm{N} 260^{\circ}\right)$ that dip $60^{\circ}-80^{\circ}$ towards $\mathrm{N}$ and S. These E-W trending steep normal faults bound the postalpine formations and thus the Reginio and Modi basins. They are active and form extensive zones whose thickness ranges from 100 to $500 \mathrm{~m}$, within which tens of smaller subparralel faults are developed. 
Fault groups 1 and 2 intersect and deform only the alpine basement rocks. Faults of group 2 were initially activated as strike slip during the thrusting emplacement and later were reactivated during the early post-alpine era, whereas with the faults of group 1 controlled the geomorphology creating horsts and grabens. Faults of group 1 are parallel to the major neighboring NW-SE trending detachments of Beotikos-Kifissos and Aghios Konstantinos that outcrop southwards and northwards our study area. These low angle extensional faults were active during Upper Miocene-Lower Pliocene, formed the early postalpine basins and then were crosscut by the Upper Pliocene-Quaternary high angle E-W trending normal faults (Papanikolaou and Royden 2007). Thus, faults of group 3 are the youngest deform both the alpine and postalpine formations crosscut also the faults of groups 1 and 2, and form the present day deformation pattern (Roberts and Ganas 2000).

Towards the northern part of the study area the major Kallidromo fault zone dominates the geomorphological and the geological structure. It trends E-W $\left( \pm 15^{\circ}\right)$ for at least $36 \mathrm{~km}$ and forms the boundary between the alpine and the postalpine formations. It is an active fault, whose activity is evidenced also by the steep slopes towards the fault plane and the incised catchments that are perpendicular to the fault trace, draining the footwall block. Several breccia of various thicknesses are observed along strike the fault zone as well. Northwards the Kallidromo fault zone, the Reginio basin is developed parallel to the zone at a mean elevation of $150 \mathrm{~m}$. This basin northwards is related to the Sperchios basin, through the Kamena Vourla fault. The Kallidromo fault zone has a thickness of $300-500 \mathrm{~m}$, separates the alpine and the postalpine formations and comprises of a large number of parallel and subparallel faults. The fault plane dips at $75^{\circ}$ to $80^{\circ}$ northwards, downthrows the topography for at least $400 \mathrm{~m}$ (from $700 \mathrm{~m}$ to $300 \mathrm{~m}$ elevation). The characteristics of the subparralel faults show that fault activity has now shifted northwards to the lower fault planes following a progressive hanginwall directed migration, which is a common feature in several active normal faults in Greece and elsewhere (e.g. Stewart and Hancock 1994). It displays all characteristics of active faulting such as free face and a cataclastic zone of approximately $5 \mathrm{~m}$. It is also probable that the extensive sliding of the ophiolites within the post-alpine formations can be attributed to the initial activity of this fault zone.

The southern part in Modi Basin forms a step-by step monoclinal structure that gradually subsides the area from the $600 \mathrm{~m}$ to approximately $150 \mathrm{~m}$ elevation up to the Beotikos Kifissos basin. All faults that are NE-SW trending are considered inactive, except the fringe fault towards the southern part of the Kallidromo Mt. This fault towards its early history bounded the alpine formations. However, it is interesting to note that this structure influenced the conglomerates as well. Indeed, along strike its trace the conglomerates have been ruptured and several small offsets $(1-2 \mathrm{~m})$ have been observed, followed by a gradual decrease of their thickness. The fault plane dips at $75^{\circ}$ towards the SE $\left(150^{\circ}\right)$. The ruptured breccia-conglomerates shows: a) a significant right lateral sense of movement so that the fault can be characterised towards this locality as an oblique normal fault; b) that it is an active structure since these breccia were formed during the Upper Pleistocene. The open fractures that are perpendicular to the fault trace also support the above. Herein, it should be noted that despite their active characteristics, no strong historical events were recorded towards the southern part of the Kallidromo Mt. This implies that the faults are probably of low slip-rate so that their reccurrence intervals have exceeded the length of the historical catalogue.

\section{Discussion - Conclusions}

A significant mass of ulrtramafic rocks in the Kallidromo Mt, with substantial differentiations both lithological and tectonic has been thrusted on top of the Mesozoic platform, producing an extended 
mélange during the Eo-Alpine orogeny. The deformation along this thrust can also be traced through the extensive approximately E-W trending shear zones towards the lower ophiolitic members (schistosed serpentinites). The latter indicates a prolonged emplacement process, and it is highly probable that this boundary was reactivated during the alpine orogeny as well.

Overall, the above measurements clearly show that two distinct deformation phases (D1, D2) are traced. Deformation D1 relates to the Upper Jurrasic-Lower Cretaceous ophiolitic emplacement and is the predominant feature over the entire study area. Fold axes, the predominant schistocity planes and shear zones clearly follow a N295 $\left( \pm 10^{\circ}\right)-115^{\circ}\left( \pm 10^{\circ}\right)$ trend. The approximately $20^{\circ}$ difference of the deformation axis between the carbonates $\left(\sim 305^{\circ}\right)$ and the overlying nappes $\left(\sim 285^{\circ}\right)$ demonstrates that an anticlockwise rotation occurred during the ophiolitic emplacement, indicating a prolonged emplacement process, that is also confirmed by the prevailing D1 deformation phase in the deformed rocks. Deformation D2 relates to the Cretaceous-Eocene alpine orogeny and follows a $\mathrm{N} 020^{\circ}\left( \pm 15^{\circ}\right)$ $\mathrm{N} 200^{\circ}\left( \pm 15^{\circ}\right)$ trend. This deformation has a much weaker imprint in the study area. In particular, it is not traced in the carbonates and the thrusts of the area as the D1 does. Moreover, D2 created the secondary schistocity plane and shear zone directions. The latter are also confirmed in the neighboring Eastern Chlomon locality, whereas the D2 phase clearly affects only the transgressive Cretaceous-Eocene sequence and refolds the E-W trending thrusts and axes of the Eo-alpine phase below the Cenomanian unconformity (Papanikolaou 2009). D2 in Easter Chlomon deforms the Upper Cretaceous and the Paleocene-Eocene flysch and thrusts follow a NNE-SSW to NE-SW trend. Similar D1 and D2 phases are also traced in the neighboring eastern Othris mountain and a similar $10^{\circ}-15^{\circ}$ anticlockwise rotation during the nappe emplacement of the D1 phase has also been observed ((Migiros 1990). This $\mathrm{N} 020^{\circ}\left( \pm 15^{\circ}\right)-\mathrm{N} 200^{\circ}\left( \pm 15^{\circ}\right)$ trend of the Alpine deformation phase D2, is almost perpendicular to the usual NW-SE alpine trend. The latter implies that the entire region from the Chlomon (Papanikolaou 2009), to Kallidromo (current study) and eastern Othris (Migiros 1990) are part of a block that experienced more or less similar post-Eocene rotations.

The post-alpine formations (Upper Pliocene to Holocene) rest uncomformably on the alpine ones and cover the Reginio and Modi basins. The Upper Pliocene-Upper Pleistocene formations comprise mostly clastic sediments of river and lake origin and are characterized by significant lateral changes in composition and thickness, demonstrating that their depositional processes were highly variable. The latter indicates that sedimentation was disrupted and controlled by the tectonic processes that occurred during the formation and initial deepening of the early post-alpine basins. Figure $2 \mathrm{~b}$ shows this differentiation of the post-alpine sediments between the Reginio and Modi basins, reflecting also the diverse neotectonic environments in both basins.

Three extensional fault groups have been defined. Faults of group $1\left(\mathrm{~N} 310^{\circ}-\mathrm{N} 130^{\circ}\right.$ trending) correlate to the early detachment related extensional phase of Upper Miocene-Lower Pliocene. Faults of group $2\left(\mathrm{~N} 030^{\circ}-\mathrm{N} 210^{\circ}\right.$ trending), were initially acted as strike slip and then reactivated as normal. Finally, group 3 represents the present-day approximately E-W trending $\left(\mathrm{N} 080^{\circ}-\mathrm{N} 260^{\circ}\right)$ high angle active normal faults that express the present-day deformation field, whereas the Kallidromo fault zone that bounds the Reginio basin forms the predominant such active structure in our study area. It is suggested that the Kallidromo is part of an E-W to ENE-WSW trending major structure, whose activity has progressively been shifted northwards towards the Kamena Vourla.

\section{References}

Aubouin, J., 1959. Contribution a l' etude geologique de la Grece septentrionale: les confins de l'Epire et la Thessalie. Ann. Geol. Pays Hell., 10, 1-484 Athenes. 
Bernoulli, D. and Laubscher, H., 1972. The palinspastic problem of the Hellenides. Eclogae geologicae Helvetiae, 65, 107-118.

Brunn, J.H., 1956. Contribution à l'étude géologique du Pinde septentrional et d'une partie de la Macédoine occidentale. Ann. Geol. Pays Hellen., 7, 1-358.

Celet, P., 1962. Contribution a l'étude géologique du Parnasse-Kiona et d'une partie des régions méridionales de la Grèce continentale. Ann. Geol. Pays Hellen., 13, 1-446, Athènes.

Clement, B., 1977. Relations structurales entre la zone du Parnasse et la zone Pélagonienne en Béotie (Grèce continentale). VI Colloquium on the Geology of the Aegean Region, Edit. G. Kalergis, IGME, 237-245, Athens.

Coleman, R.C., 1977. Ophiolites-ancient oceanic lithosphere. 229, Springer, Berlin/Heidelberg/New York.

Faupl, P., Pavlopoulos, A., Wagreich, M., Migiros, G., 1996. Pre-Tertiary blueschist terrains in the Hellenides: evidence from detrital minerals of flysch successions. Terra Nova, 8, 186-190.

Ferriere, J., 1982. Paléogéographies et tectoniques superposées dans les Hellénides internes au niveau de l' Othrys et du Pélion (Grece). Thèse, sciences, Univ. Lille et Soc. Geol. Nord. Publ. No 8, 970p., Lille.

Fleury, J., 1980. Les zones de Gavrovo-Tripolitsa et du Pindos - Olonos (Grece continentale et Péloponnèse du Nord). Evolution d' une plateforme et d' un bassin dans leur cadre alpin. Soc. Geol. Nord., 4,651p., Lille.

Ganas, A., 1997. Fault segmentation and seismic hazard assessment in the Gulf of Evía rifft, Central Greece. Unpub1. PhD Thesis, Univ. of Reading, 369 p.

Goldsworthy, M. and J. Jackson, 2001. Migration of activity within normal fault systems: examples from the Quaternary of mainland Greece. J. Struct. Geol.23, 489-506.

Jacobshagen, V., 1986. Geologie von Griechenland.Berlint:Gebrüder Borntraeger, 363 p.

Jones, G. and Robertson, A.G.F., 1991. Tectono-stratigraphy and evolution of the Mesozoic Pindos ophiolites and related units, Northwestern Greece. J. Geol. Soc. London, 148, 267-288.

Karipi, S., Tsikouras, B., Hatzipanagiotou, K. and Grammatikopoulos, T.A., 2007. Petrogenetic significance of spinel-group minerals from the ultramafic rocks of the Iti and Kallidromon ophiolites (Central Greece). Lithos 99, 136-149.

Katsikatsos, G., Migiros G., Triantaphylis M., Mettos A., 1986. Geological structure of Internal Hellenides (E. Thessaly, SW Macedonia, Euboea-Attica-Northern Cyclades Islands and Lesvos). Geol. \& Geoph. Res., Special Issue, I.G.M.E., 191-212, Athens.

Kranis, H.D., 1999. Neotectonic activity of fault zones in Lokris, central-eastern mainland Greece. PhD thesis, University of Athens, 234p.

Migiros, G., 1990. The lithostratigraphic - tectonic structure of Othris (Central Greece). Bulletin of the Geological Society of Greece XXVI, 107-120 (in Greek).

Mountrakis, D., Sapounzis, E., Kilias, A., Eleftheriadis, G. and Christofides, G., 1983. Paleogeographic conditions in the western pelagonian margin in Greece during the initial rifting of the continental area. Can. J. Earth Sci., 20, 1673-1681.

Papanikolaou, D., 1989. Are the Medial Crystalline Massifs on the Eastern Mediterranean drifted Gondwanian fragments? Sp. Publ. Geol.Soc., Greece, 1, 63-90.

Papanikolaou, D., 2009. Timing of tectonic emplacement of the ophiolites and terrane paleogeography in the Hellenides. Lithos 108, 262-280.

Papanikolaou, D. and Royden, L., 2007. Disruption of the Hellenic arc: Late Miocene extensional detachment faults and steep Pliocene-Quaternary normal faults - or - What happened at Corinth? Tectonics, 26, TC5003, doi:10.1029/2006TC002007. 
Phillip, H., 1974. Etude néotectonique des ravages egeens en Locride et en Eubée nord-occidentale (Grèce). Thèse de 3o Cycle, Univ. des Sciences et Techniques du Languedoc, Montpellier, 86p.

Papastamatiou, I., Tataris, A., Vetoulis, D., Katsikatsos, G., Lalechos, N., and Eleftheriou, A., 1962. Geological Map of Greece, 1:50.000 scale Amfiklia Sheet, IGME.

Roberts, G.P. and Ganas, A., 2000. Fault-slip directions in central-southern Greece measured from striated and corrugated fault planes: comparison with focal mechanism and geodetic data. J. Geophys. Res., 105, 23,443-23,462.

Smith, A.G. and Woodcock, N.H., 1976. Emplacement model for some "Tethyan" ophiolites. - Geology, 4, 653-656.

Stewart, I.S. and Hancock, P.L., 1994. Neotectonics. In continental deformation Hancock, P.L. (ed), Pergamon Press, 370-409. 